\title{
Celiac Disease and Autoimmune Thyroid Disease
}

\author{
Chin Lye Ch'ng, MRCPI; M. Keston Jones, MD, FRCP; and Jeremy G. C. Kingham, MD, FRCP
}

\begin{abstract}
Celiac disease (CD) or gluten sensitive enteropathy is relatively common in western populations with prevalence around $1 \%$. With the recent availability of sensitive and specific serological testing, many patients who are either asymptomatic or have subtle symptoms can be shown to have CD. Patients with CD have modest increases in risks of malignancy and mortality compared to controls. The mortality among CD patients who comply poorly with a gluten-free diet is greater than in compliant patients. The pattern of presentation of $C D$ has altered over the past three decades. Many cases are now detected in adulthood during investigation of problems as diverse as anemia, osteoporosis, autoimmune disorders, unexplained neurological syndromes, infertility and chronic hypertransaminasemia of uncertain cause.
\end{abstract}

Among autoimmune disorders, increased prevalence of $C D$ has been found in patients with autoimmune thyroid disease, type I diabetes mellitus, autoimmune liver diseases and inflammatory bowel disease. Prevalence of CD was noted to be $1 \%$ to $19 \%$ in patients with type I diabetes mellitus, $2 \%$ to $5 \%$ in autoimmune thyroid disorders and $3 \%$ to $7 \%$ in primary biliary cirrhosis in prospective studies. Conversely, there is also an increased prevalence of immune based disorders among patients with CD. The pathogenesis of co-existent autoimmune thyroid disease and CD is not known, but these conditions share similar HLA haplotypes and are associated with the gene encoding cytotoxic T-lymphocyte-associated antigen-4.

Screening high risk patients for CD, such as those with autoimmune diseases, is a reasonable strategy given the increased prevalence. Treatment of $C D$ with a gluten-free diet should reduce the recognized complications of this disease and provide benefits in both general health and perhaps life expectancy. It also improves glycemic control in patients with type I diabetes mellitus and enhances the absorption of medications for associated hypothyroidism and osteoporosis. It probably does not change the natural history of associated autoimmune disorders.

Keywords: Autoimmune thyroid disease; Celiac disease; Prevalence; Screening

$\mathrm{C}$ permanent intolerance of dietary gluten leading to mucosal damage in the proximal small bowel in genetically susceptible individuals, characterized by inflammation, crypt hyperplasia and villous atrophy which regress on withdrawal of gluten from the diet. Recent population screening studies have shown the prevalence of $C D$ in Western countries approaches $1 \%^{1-3}$ but the condition is greatly under-diagnosed, partly because many cases are subclinical, but also because of its previously perceived rarity.
CD should be considered in many clinical settings and detected early to prevent complications in later life. In a 6-year prospective study, Corrao et $\mathrm{al}^{4}$ followed 1,072 consecutive $\mathrm{CD}$ patients and found a standard mortality ratio of 0.5 in those who complied with a strict gluten-free diet but a standard mortality ratio of 6.0 in the poor compliers. Using the general practice research database, West et $\mathrm{al}^{5}$ identified 4,732 CD patients and found a modest increase in overall risks of malignancy and mortality compared to matched controls.
Reprint Requests: Dr. Jeremy G. C. Kingham, Singleton Hospital, Sketty, Swansea SA2 8QA, United Kingdom, Tel/Fax: 01792 28503I, Email: jkingham@swansea-tr.wales.nhs.uk
Received: December 5, 2006 Revised: April 2, 2007 Accepted: May 4, 2007

doi: $10.3121 / \mathrm{cmr} .2007 .738$ 
Table 1. Manifestations of silent celiac disease (predominantly extra-intestinal).

Dermatitis herpetiformis

Anemia

Autoimmune disorders

Osteoporosis

Neurological disorders

Epilepsy with cerebral calcification

Neuropathy

Cerebellar ataxia

Chorea

Infertility/subfertility

Non-alcoholic fatty liver disease

Unexplained chronic hypertransaminasemia

\section{Manifestation of CD}

Classically CD, as originally described in the $19^{\text {th }}$ century, was characterized by steatorrhea, vomiting and cachexia in early childhood. ${ }^{6}$ Over the past 30 years, the clinical presentation of $\mathrm{CD}$ has moved from overt malabsorption in childhood towards milder symptoms or atypical features in adult life. ${ }^{7-11}$ It is increasingly recognized, however, that symptomatic cases represent only the tip of a celiac iceberg. Many patients with $\mathrm{CD}$ have either no or very subtle symptoms (silent $\mathrm{CD})^{12}$ and are diagnosed through family or occasional screening.

\section{Diagnosis of and Screening Tools for CD}

The revised diagnostic criteria for CD by the working group of the European Society of Paediatric Gastroenterology and Nutrition ${ }^{13}$ take into account the usefulness of the serological tests. However, identification of the histological changes in proximal small bowel mucosa remains the gold standard.

Both $\operatorname{IgA}$ anti-endomysial antibody (EmA) and $\operatorname{IgA}$ anti-tissue transglutaminase (anti-tTG) antibody are highly sensitive when used in screening. ${ }^{14-16}$ As these are IgA-class antibodies, false-negative results occur in IgA-deficiency which itself is associated with CD. ${ }^{17}$ Patients with IgA-deficiency should be tested with IgG-class anti-tTG ${ }^{17}$ or EmA, ${ }^{18}$ or be offered distal duodenal biopsy.

HLA typing may have a role in the diagnostic algorithm, especially in excluding the diagnosis. Negative HLA-DQ2 heterodimer or DQ8 or one-half of the DQ2 heterodimer virtually excludes susceptibility to $C D$ with negative predictive values approaching 100\%. ${ }^{19,20}$

\section{Why Should Non-Gastroenterologists Recognize CD?}

Gastroenterologists are already familiar with the association of CD with several immune and non-immune based diseases in the digestive system, including ulcerative colitis, ${ }^{21,22}$ Crohn's disease, ${ }^{23}$ microscopic colitis, ${ }^{24}$ autoimmune liver diseases, ${ }^{25-27}$ fatty liver ${ }^{28}$ and elevated liver transaminase levels. ${ }^{29-32}$ However, many diseases outside the digestive system have also been linked with $\mathrm{CD}$, both in its overt and silent forms.

The association of dermatitis herpetiformis ${ }^{33-36}$ with gluten sensitive enteropathy is widely recognized. Diseases most typically associated with silent $\mathrm{CD}$ are immune-based disorders, such as type 1 diabetes mellitus, ${ }^{21,37-40}$ autoimmune thyroid diseases, ${ }^{21,38,39,41,42}$ Sjögren's syndrome ${ }^{37,38}$ and Addison's disease. ${ }^{43,44}$ An association with atopy has also been described, ${ }^{21,45,46}$ but this has been disputed. 47 Other disease associations of uncertain pathogenesis include dental enamel defects, ${ }^{48-50}$ epilepsy with cerebral calcification, ${ }^{51}$ neuropathy, ${ }^{52,53}$ cerebellar ataxia, ${ }^{54,55}$ chorea $^{56}$ and infertility 57,58 (table 1).

It is possible that some previously suggested disease associations may simply be chance findings. Nonetheless, recent screening studies in patients with type 1 diabetes mellitus, ${ }^{59-63}$ autoimmune thyroid disease (table 2), primary biliary cirrhosis $25-27,64$ and Crohn's disease ${ }^{23}$ suggest that these relationships are real, making screening worthwhile (table 3).

CD satisfies the World Health Organization (WHO) criteria for general population screening ${ }^{65}$ but this proposal remains controversial. 66 The most practical approach may be to screen subjects at increased risk, such as family members of an index case or patients with disorders known to be associated with CD. Diagnosis in this latter group is particularly important because of the increased morbidity of one disease superimposed on the other.

Table 2. Prevalence of celiac disease (CD) in autoimmune thyroid disorders.

\begin{tabular}{llc}
\hline Author (year of publication) & Population screened & Prevalence of CD \\
\hline Collin et al $(1994)^{41}$ & 83 autoimmune thyroid disease & $4.8 \%$ \\
Sategna-Guidetti et al $(1998)^{76}$ & 152 autoimmune thyroid disease & $3.3 \%$ \\
Cuoco et al $(1999)^{78}$ & 22 Hashimoto's disease & $4.3 \%$ \\
& 23 Graves' disease & $3.3 \%$ \\
Valentino et al $(1999)^{77}$ & 150 autoimmune thyroid disease & $3.5 \%$ \\
Berti et al $(2000)^{79}$ & 172 autoimmune thyroid disease & $3.2 \%$ \\
Volta et al $(2001)^{80}$ & 220 autoimmune thyroid disease & $7.8 \%$ \\
Larizza et al $(2001)^{81}$ & 90 Pediatric autoimmune thyroid disease & $4.4 \%$ \\
Meloni et al $(2001)^{82}$ & 297 autoimmune thyroid disease & $2 \%$ \\
Mainardi et al $(2002)^{83}$ & 100 autoimmune thyroid disease & $4.5 \%$ \\
Ch'ng et al $(2005)^{42}$ & 115 Graves' disease & \\
\hline
\end{tabular}


Table 3. Autoimmune disorders associated with celiac disease through screening.

\begin{tabular}{ll}
\hline Conditions & Prevalence of celiac disease \\
\hline Type 1 diabetes mellitus & $1 \%$ to $16 \% \%^{59-63,104,105}$ \\
Autoimmune thyroid disease (adult) & $2 \%$ to $4.8 \%{ }^{41,42,76-83}$ \\
Pediatric autoimmune thyroid disease & $7.8 \%^{81}$ \\
Primary biliary cirrhosis & $3 \%$ to $7 \%^{25-27}$ \\
Crohn's disease & $19 \%^{23}$ \\
\hline
\end{tabular}

\section{Thyroid Dysfunction in CD and Dermatitis Herpetiformis (table 4)}

An increased prevalence of thyroid dysfunction has been reported in patients with $\mathrm{CD}$. In a study from Sweden where the prevalence of $C D$ was 95.5 per 10,000 , Midhagen et al ${ }^{67}$ found that thyrotoxicosis occurred in $5.0 \%$ and spontaneous hypothyroidism in $5.8 \%$ of the celiac patients. These thyroid disorders were sometimes diagnosed before, and sometimes after, the diagnosis of $\mathrm{CD}$ and instigation of the gluten-free diet. The duration of the gluten-free diet in relation to the diagnosis of thyroid disease was not stated. In a cohort of 70 celiac patients, Volta et al ${ }^{68}$ noted four with hypothyroidism and one with thyrotoxicosis. They concluded that the finding of autoantibodies in celiac patients suggested the coexistence of a wide spectrum of immunological diseases including type 1 diabetes mellitus, autoimmune hepatitis, dermatomyositis and thyroid disorders. Reunala and Collin ${ }^{38}$ followed 305 patients with dermatitis herpetiformis and 383 with $\mathrm{CD}$ for a mean of 10 years and found $4.3 \%$ and $6.0 \%$ had autoimmune thyroid disease, respectively. These patients were all on a gluten-free diet and were also taking dapsone if suffering from dermatitis herpetiformis. Four patients with dermatitis herpetiformis developed hypothyroidism and three patients with CD developed thyroid disorders (two hypothyroidism and one hyperthyroidism) during follow-up, while on a gluten-free diet. Cooper et $\mathrm{al}^{21}$ reported 11 patients with thyroid disorders among 314 patients with $\mathrm{CD}$; three of these 11 patients (two with thyrotoxicosis and one myxoedema) were diagnosed while on a gluten-free diet. Collin et al ${ }^{69}$ found $5.4 \%$ of 335 adult celiac patients, of whom $83 \%$ complied with a gluten-free diet, had autoimmune thyroid disease (autoimmune hypothyroidism or Graves' disease). Counsell et $\mathrm{al}^{70}$ found that $14 \%$ (15 out of 107) of celiac patients had thyroid disorders (3.7\% hyperthyroid and $10.3 \%$ hypothyroid). Eleven of these 15 patients were known to have prior autoimmune thyroid disease ( 8 autoimmune hypothyroidism and 3 Graves' disease), three were found to have thyroid disease at the time when CD was diagnosed and one developed hypothyroidism 5 months after the diagnosis of $\mathrm{CD}$ and introduction of a gluten-free diet. The same authors also noted a high prevalence of thyroglobulin antibodies (11\%) and thyroid microsomal antibodies (15\%) in their CD patients. Likewise, Velluzzi et $\mathrm{al}^{71}$ found the prevalence of thyroid peroxidase antibodies to be higher in CD (29.7\%, 14 out of 47 patients) than in healthy controls (9.6\%). In five of these 14 patients, two had mild hypothyroidism and three subclinical hypothyroidism. They did not find any difference between celiac patients with or without serological or ultrasonographic evidence of thyroid disease in relation to age, disease duration, histological abnormalities and titer of immunological markers of CD. In a prospective cohort of 90 children with $\mathrm{CD}$, Ventura et al ${ }^{39}$ reported $14.4 \%$ to have thyroid autoantibodies at the time of $\mathrm{CD}$ diagnosis. Kowalska et al ${ }^{72}$ observed elevated titers of antithyroid antibodies in 34 poorly compliant IgA-EmA positive children with $\mathrm{CD}(41 \%)$ compared to controls (3.6\%) who were seen because of dyspepsia.

In a prospective study of 241 untreated celiac patients, Sategna-Guidetti et $\mathrm{al}^{73}$ found hypothyroidism in $12.9 \%$ which was 3 -fold higher than in controls $(4.2 \%)$. Autoimmune thyroid disease with euthyroidism was found in 39 patients $(16.2 \%)$ and 8 controls $(3.8 \%)$. There was no increase in hyperthyroidism. In 128 patients, intestinal biopsy and thyroid function were repeated within a year. Among those who followed a strict gluten-free diet, there was an apparent normalization of subclinical hypothyroidism. Four of 16 patients with autoimmune thyroid disease with euthyroidism were found to have subclinical thyroid disease (three hypothyroidism and one hyperthyroidism). Five out of 91 celiac patients with normal thyroid function developed thyroid disease (two hypothyroidism, one subclinical hyperthyroidism and two autoimmune thyroid disease with euthyroidism). Hakanen et $\mathrm{al}^{74}$ found clinical autoimmune thyroid disease in $13.9 \%$ of 79 celiac patients in contrast to $2.1 \%$ of 184 controls, and subclinical thyroid disease in $10.1 \%$ and $3.3 \%$, respectively. There was no difference in the presence of circulating thyroid antibodies (thyroid peroxidase and microsomal antibodies) in relation to the duration of gluten withdrawal $(20 \%$ in patients on a gluten-free diet $>4$ years vs. $17 \%$ in patients on a gluten-free diet $<4$ years). Carta et $\mathrm{a}^{75}$ found an increased prevalence of thyroid peroxidase antibodies among 36 adult celiac patients (30.5\% in CD vs. $9.7 \%$ in controls) and suggested subclinical thyroid disease might pose a risk for psychiatric illness, such as panic attacks and major depressive disorders. In patients with major depressive disorders, gastrointestinal symptoms had started earlier (before age 5) than those without. They also concluded that a gluten-free diet did not protect against development of major depressive and panic disorders.

\section{CD in Autoimmune Thyroid Disease (table 2)}

Screening 83 Finnish patients with autoimmune thyroid disease for $\mathrm{CD}$ using IgA-class reticulin and endomysium antibody, IgA- and IgG-class gliadin antibody tests and various biochemical tests for malabsorption, Collin et al ${ }^{41}$ 


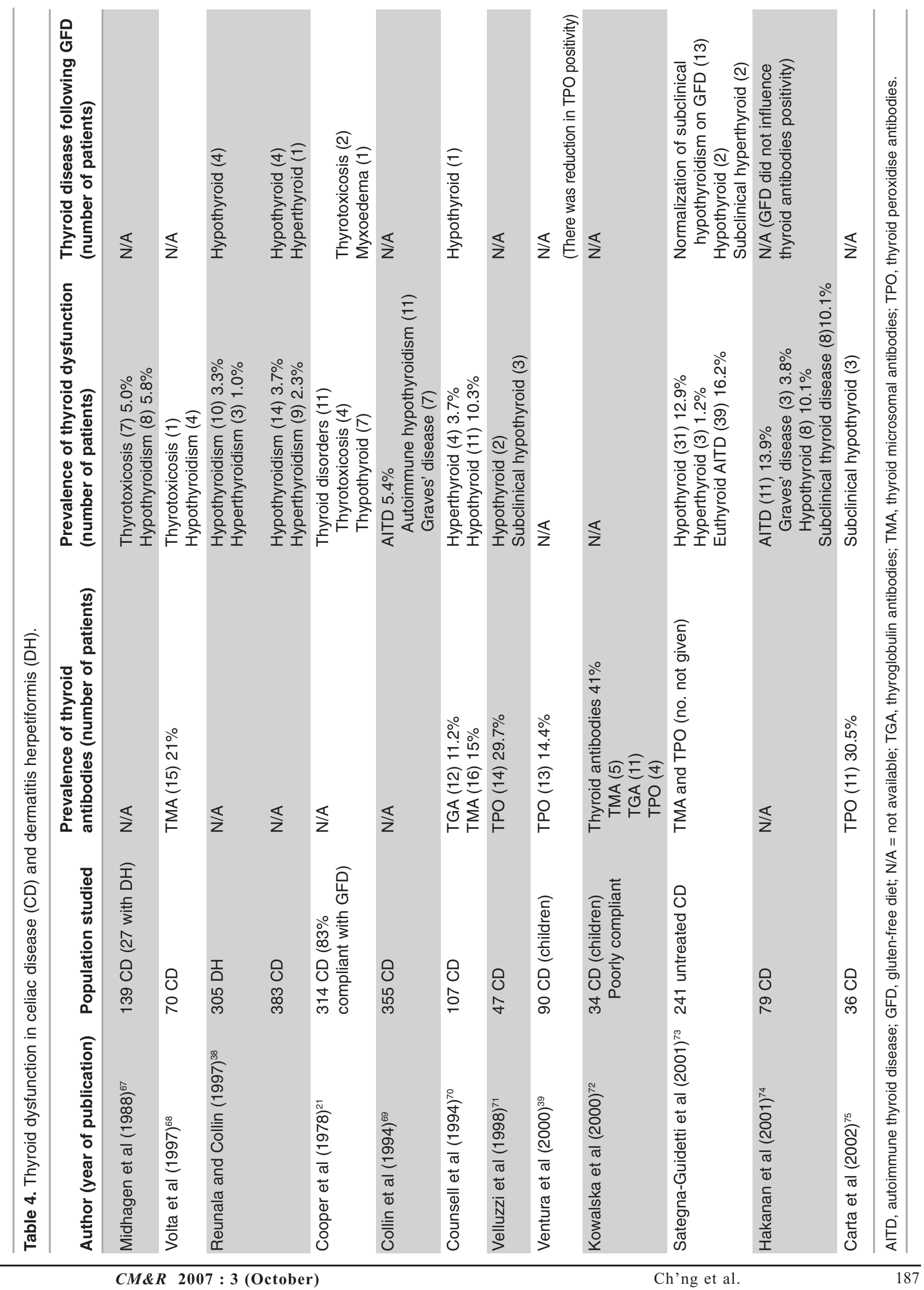


found three asymptomatic celiac patients which, with one previously diagnosed $\mathrm{CD}$ patient, gave an overall frequency of $4.8 \%$. In addition, 25 patients with a solitary thyroid nodule were examined and one (4\%) was found to have CD. In contrast, one $(0.4 \%)$ out of 249 age- and sex-matched blood donors was found to have $\mathrm{CD}$. All newly detected celiac patients had IgA-class gliadin, reticulin and endomysium antibodies, but none had gastrointestinal symptoms or abnormal biochemical findings suggestive of $\mathrm{CD}$. Sategna-Guidetti et al ${ }^{76}$ found that $3.3 \%$ (5 of 152) of patients with autoimmune thyroid disease also had CD using IgA-EmA and confirmed on duodenal histology. Only one patient presented with gastrointestinal complaints, but iron deficiency was found in three and alterations in bone mineral density in all five. Valentino et al ${ }^{77}$ screened 150 newly diagnosed patients with autoimmune thyroid disease using EmA and found five (3.3\%) to have CD. Patients improved on a gluten-free diet with amelioration in hypothyroidism and thyroxine dose reduction. Cuoco et al ${ }^{78}$ studied 92 patients with autoimmune thyroid disease (47 chronic autoimmune thyroiditis of which 22 were Hashimoto's thyroiditis and 23 Graves' disease) and looked for serological evidence of CD with anti-gliadin antibody (AGA) and EmA. Four patients (5.4\%) were found to have $\mathrm{CD}$ confirmed by endoscopic duodenal biopsy in contrast to $1.1 \%$ of those with non-autoimmune thyroid disease and $0.4 \%$ of healthy blood donors. They also found AGA to be less specific than EmA. Berti et al ${ }^{79}$ found six of their $172(3.4 \%)$ patients with autoimmune thyroid disease to be EmA positive; five of these underwent small bowel biopsies and all showed total villous atrophy in contrast to $0.75 \%$ of 396 patients with non-gastrointestinal malignancies and $0.25 \%$ of 4,000 blood donors. Volta et $\mathrm{al}^{80}$ analyzed sera from 220 patients with autoimmune thyroiditis, 50 euthyroid subjects with thyroid nodules and 250 healthy blood donors for AGA and EmA. Among those with autoimmune thyroiditis, seven had positive serology and villous atrophy. None of the euthyroid patients with thyroid nodules and only one blood donor were found to have $\mathrm{CD}$. Larizza et al ${ }^{81}$ screened 90 children and adolescents with autoimmune thyroid disease and showed seven to have $\mathrm{CD}$ (prevalence of 1 in 13) and recommended that children with autoimmune thyroid disease be screened. Meloni et al ${ }^{82}$ screened 297 Sardinian patients with autoimmune thyroid disease with IgA-class and IgG-class AGA. Those found to be positive with either antibody were further tested for EmA. If any two markers were positive, hematinics were determined and the patients offered a jejunal biopsy. Thirteen of 14 patients who showed at least two positive markers underwent jejunal biopsy and all showed histological features of $\mathrm{CD}$. The prevalence of $\mathrm{CD}$ was found to be $4.4 \%$ among patients with autoimmune thyroid disease. No patients had gastrointestinal symptoms, although half had hematinic deficiencies. Six had iron deficiency, two were deficient in vitamin $\mathrm{B}_{12}$ but none was folate deficient. Mainardi et a ${ }^{83}$ found the prevalence of $\mathrm{CD}$ among their cohort of 100 patients with autoimmune thyroid disease to be $2 \%$. These studies confirm that the frequency of subclinical $\mathrm{CD}$ is increased in patients with autoimmune thyroid disease. IgA-class antibody tests are suitable for screening, as long as selective IgA-deficiency is excluded.

\section{CD in Graves' Hyperthyroidism}

None of the previous studies looked at the prevalence of CD solely in patients with Graves' hyperthyroidism. Ch'ng et al ${ }^{42}$ evaluated the role of screening for $\mathrm{CD}$ prospectively in a consecutive cohort of 115 patients with Graves' hyperthyroidism attending a secondary care thyroid clinic using AGA and IgA-class anti-tTG antibodies. Two patients were already known to have $\mathrm{CD}$ and were asymptomatic on a gluten-free diet. Three new celiac patients were found during screening which, with the two existing celiac patients, gave a CD prevalence of $4.5 \%$ compared to $0.9 \%$ (1 of 115 ) of sexand age-matched blood donor controls. All five patients had silent $\mathrm{CD}$ with no gastrointestinal symptoms. In the two existing celiac patients, the diagnosis of Graves' hyperthyroidism preceded that of CD by 3 and 26 years. The latter patient had a long history of unexplained neurological disease. On the basis of this study, serological screening for CD was recommended for patients with Graves' hyperthyroidism.

\section{Pathogenesis of Co-Existent Autoimmune Thyroid Disease and CD}

The coexistence of $\mathrm{CD}$ and autoimmune disease is thought to be partly due to a common genetic predisposition. HLA-DQ2 and DQ8 haplotypes are over-represented in many autoimmune diseases ${ }^{84-87}$ and the inheritance of these haplotypes ${ }^{88}$ and the associated immunological phenotype may explain the link. Sharing similar HLA genotypes may also explain the strong association between IgA-deficiency and CD. HLA-DQ2 and DQ8 show a weak association with Hashimoto's thyroiditis, although HLA-DQ2 association is less clear in Graves' disease. 89,90

Outside the HLA region, both CD and autoimmune thyroid disease are reported to be associated with the gene encoding cytotoxic T-lymphocyte-associated antigen-4 (CTLA-4), a candidate gene for conferring susceptibility to thyroid autoimmunity. ${ }^{91-93}$ More recently, a study showed that 10 of 14 patients with Hashimoto's thyroiditis had genotypes compatible with $\mathrm{CD}$ (three patients had DQ heterodimer A1*0501, B1*0201, four had DRB1*04 and one had $\mathrm{A} 1 * 0101, \mathrm{~B} 1 * 0501$ ). Six of these 14 patients showed an increased density of $\gamma \delta^{+}$T-cell receptor-bearing intra-epithelial lymphocytes and signs of mucosal T-cell activation, both typical of CD. ${ }^{94}$ Also among 4 of these 6 patients, HLA genotypes associated with $C D$ (three with DRB1*04, DQB1*03 and one with DQA1*0501, DQB1*02) were described.

Can Treatment of CD Change the Course/ Development of Associated Autoimmune Disorders? Identifying and treating $\mathrm{CD}$ in high-risk patients should confer benefit in reducing complications such as 
malabsorption, infertility, osteoporosis and lymphoma. ${ }^{95,96}$ Treatment also improves the absorption of medications for the associated conditions such as hypothyroidism 77,97 and osteoporosis. ${ }^{98}$ It is not known whether treatment of CD reduces the likelihood of developing autoimmune disorders, or changes their natural history. Cooper et $\mathrm{al}^{21}$ considered that a gluten-free diet did not prevent development of autoimmune disorders and had little ameliorating effect on their course, apart from an occasional improvement in atopy. Sategna-Guidetti et al, ${ }^{73,99}$ however, noted that a gluten-free diet may reverse the abnormality in those with subclinical hypothyroidism although, like Viljamaa et al,100 found no correlation between duration of gluten exposure in adult CD and risk of autoimmune disorders. Ventura et $\mathrm{al}^{39}$ found that diabetes- and thyroid-related antibodies tended to disappear following a gluten-free diet $(11.1 \%$ at diagnosis, $5.6 \%$ at 6 months and none at 12 or 24 months follow-up for diabetes related antibodies and $14.4 \%, 11.1 \%, 6.6 \%$ and $2.2 \%$ for thyroid related antibodies, respectively) while Mainardi et $\mathrm{al}^{83}$ found no correlation between thyroid antibodies and the introduction of a gluten-free diet. Among their cohort of $9 \mathrm{CD}$ patients with autoimmune cholestatic liver diseases (seven primary biliary cirrhosis, one primary sclerosing cholangitis and one autoimmune cholangiopathy) detected through screening, Volta et $\mathrm{al}^{27}$ did not observe any clinical or biochemical improvement in cholestasis following a gluten-free diet. A gluten-free diet probably should be started early, before autoimmune disorders are well established, to affect their course. Rami et al, ${ }^{101}$ studying diabetic children, found that silent $\mathrm{CD}$ had no obvious effect on metabolic control but negatively influenced weight gain. SanchezAlbisua et al, ${ }^{102}$ on the other hand, showed an increase in height and weight and a trend towards improved glycemic control in diet-compliant celiac patients diagnosed through screening type 1 diabetic children. Acerini et al ${ }^{59}$ also showed improvement in weight and glycemic control in those treated with a gluten-free diet. Kaspers et al ${ }^{103}$ found that children with type 1 diabetes and CD were characterized by earlier onset of diabetes and decreased growth and weight gain. These findings emphasize the clinical relevance of $\mathrm{CD}$ in patients with autoimmune diabetes.

\section{Conclusion}

Patients with CD may present with diverse clinical manifestations, or without symptoms, to specialists other than gastroenterologists. There is ample evidence of a strong association between $\mathrm{CD}$ and several immune mediated diseases, including autoimmune thyroid disorders, type 1 diabetes mellitus, primary biliary cirrhosis, inflammatory bowel diseases and autoimmune adrenal failure. Some of these conditions share HLA haplotypes and non-HLA alleles, e.g., CTLA-4, which may underlie their pathogenesis. Thyroid function should be assessed in all CD patients at diagnosis and follow-up if clinically indicated. Relatively cheap serological testing kits for anti-tTG and EmA are available to screen for CD. Screening of high-risk groups such as those with autoimmune thyroid disease is a reasonable strategy. Currently there is little evidence to support a role for a gluten-free diet in reducing the development of associated autoimmune disorders in patients with $\mathrm{CD}$, but early diagnosis and dietary treatment reduces complications such as malabsorption, osteoporosis and lymphoma, and improves the absorption of drugs.

\section{References}

1. West J, Logan RF, Hill PG, Lloyd A, Lewis S, Hubbard R, Reader R, Holmes GK, Khaw KT. Seroprevalence, correlates, and characteristics of undetected coeliac disease in England. Gut 2003;52:960-965.

2. Kolho KL, Farkkila MA, Savilahti E. Undiagnosed coeliac disease is common in Finnish adults. Scand J Gastroenterol 1998;33:1280-1283.

3. Tommasini A, Not T, Kiren V, Baldas V, Santon D, Trevisiol C, Berti I, Neri E, Gerarduzzi T, Bruno I, Lenhardt A, Zamuner E, Spano A, Crovella S, Martellossi S, Torre G, Sblattero D, Marzari R, Bradbury A, Tamburlini G, Ventura A. Mass screening for coeliac disease using antihuman transglutaminase antibody assay. Arch Dis Child 2004;89:512-515.

4. Corrao G, Corazza GR, Bagnardi V, Brusco G, Ciacci C, Cottone M, Sategna Guidetti C, Usai P, Cesari P, Pelli MA, Loperfido S, Volta U, Calabro A, Certo M; Club del Tenue Study Group. Mortality in patients with coeliac disease and their relatives: a cohort study. Lancet 2001;358:356-361.

5. West J, Logan RF, Smith CJ, Hubbard RB, Card TR. Malignancy and mortality in people with coeliac disease: population based cohort study. BMJ 2004;329:716-719.

6. Gee SJ. On the coeliac affection. St Bartholomew's Hospital Reports 1888;24:17-20.

7. No authors listed. Childhood coeliac disease is disappearing. Lancet 1980;2:1359-1360.

8. Stevens FM, Egan-Mitchell B, Cryan E, McCarthy CF, McNicholl B. Decreasing incidence of coeliac disease. Arch Dis Child 1987;62:465-468.

9. Logan RF, Tucker G, Rifkind EA, Heading RC, Ferguson A. Changes in clinical features of coeliac disease in adults in Edinburgh and the Lothians 1960-79. Br Med J (Clin Res Ed) 1983;286:95-97.

10. Maki M, Kallonen K, Lahdeaho ML, Visakorpi JK. Changing pattern of childhood coeliac disease in Finland. Acta Paediatr Scand 1988;77:408-412.

11. Sanders DS, Hurlstone DP, Stokes RO, Rashid F, Milford-Ward A, Hadjivassiliou M, Lobo AJ. Changing face of adult coeliac disease: experience of a single university hospital in South Yorkshire. Postgrad Med J 2002;78:31-33.

12. Ferguson A, Arranz E, O'Mahony S. Clinical and pathological spectrum of coeliac disease - active, silent, latent, potential. Gut 1993;34:150-151.

13. No authors listed. Revised criteria for diagnosis of coeliac disease. Report of Working Group of European Society of Paediatric Gastroenterology and Nutrition. Arch Dis Child 1990;65:909-911.

14. Hill PG, Forsyth JM, Semeraro D, Holmes GK. IgA antibodies to human tissue transglutaminase: audit of routine practice confirms high diagnostic accuracy. Scand J Gastroenterol 2004;39:1078-1082.

15. Fabiani E, Peruzzi E, Mandolesi A, Garbuglia G, Fanciulli G, D’Appello AR, Gasparin M, Bravi E, Bearzi I, Galeazzi R, Catassi C. Anti-human versus anti-guinea pig tissue transglutaminase antibodies as the first-level serological screening test for coeliac disease in the general population. Dig Liver Dis 2004;36:671-676. 
16. Collin P, Kaukinen K, Vogelsang H, Korponay-Szabo I, Sommer R, Schreier E, Volta U, Granito A, Veronesi L, Mascart F, Ocmant A, Ivarsson A, Lagerqvist C, Burgin-Wolff A, Hadziselimovic F, Furlano RI, Sidler MA, Mulder CJ, Goerres MS, Mearin ML, Ninaber MK, Gudmand-Hoyer E, Fabiani E, Catassi C, Tidlund H, Alainentalo L, Maki M. Antiendomysial and antihuman recombinant tissue transglutaminase antibodies in the diagnosis of coeliac disease: a biopsy-proven European multicentre study. Eur J Gastroenterol Hepatol 2005;17:85-91.

17. Lenhardt A, Plebani A, Marchetti F, Gerarduzzi T, Not T, Meini A, Villanacci V, Martelossi S, Ventura A. Role of human-tissue transglutaminase IgG and anti-gliadin IgG antibodies in the diagnosis of coeliac disease in patients with selective immunoglobulin A deficiency. Dig Liver Dis 2004;36:730-734.

18. Cataldo F, Lio D, Marino V, Picarelli A, Ventura A, Corazza GR. IgG(1) antiendomysium and IgG antitissue transglutaminase (anti-tTG) antibodies in coeliac patients with selective IgA deficiency. Working Groups on Celiac Disease of SIGEP and Club del Tenue. Gut 2000;47:366-369.

19. Sollid LM, Lie BA. Celiac disease genetics: current concepts and practical applications. Clin Gastroenterol Hepatol 2005;3:843-851.

20. Margaritte-Jeannin P, Babron MC, Bourgey M, Louka AS, Clot F, Percopo S, Coto I, Hugot JP, Ascher H, Sollid LM, Greco L, Clerget-Darpoux F. HLA-DQ relative risks for coeliac disease in European populations: a study of the European Genetics Cluster on Coeliac Disease. Tissue Antigens 2004;63:562-567.

21. Cooper BT, Holmes GK, Cooke WT. Coeliac disease and immunological disorders. Br Med J 1978;1:537-539.

22. Ch'ng CL, Lewis S, Kingham JGC. Coeliac serology in patients with inflammatory bowel disease. Gut 2001;48[Suppl 1]:A85-A86.

23. Tursi A, Giorgetti GM, Brandimarte G, Elisei W. High prevalence of celiac disease among patients affected by Crohn's disease. Inflamm Bowel Dis 2005;11:662-666.

24. Kingham JG. Microscopic colitis. Gut 1991;32:234-235.

25. Floreani A, Betterle C, Baragiotta A, Martini S, Venturi C, Basso D, Pittoni M, Chiarelli S, Sategna Guidetti C. Prevalence of coeliac disease in primary biliary cirrhosis and of antimitochondrial antibodies in adult coeliac disease patients in Italy. Dig Liver Dis 2002;34:258-261.

26. Kingham JG, Parker DR. The association between primary biliary cirrhosis and coeliac disease: a study of relative prevalences. Gut 1998;42:120-122.

27. Volta U, Rodrigo L, Granito A, Petrolini N, Muratori P, Muratori L, Linares A, Veronesi L, Fuentes D, Zauli D, Bianchi FB. Celiac disease in autoimmune cholestatic liver disorders. Am J Gastroenterol 2002;97:2609-2613.

28. Bardella MT, Valenti L, Pagliari C, Peracchi M, Fare M, Fracanzani AL, Fargion S. Searching for coeliac disease in patients with non-alcoholic fatty liver disease. Dig Liver Dis 2004;36:333-336.

29. Novacek G, Miehsler W, Wrba F, Ferenci P, Penner E, Vogelsang H. Prevalence and clinical importance of hypertransaminasaemia in coeliac disease. Eur J Gastroenterol Hepatol 1999;11:283-288.

30. Duggan JM, Duggan AE. Systematic review: the liver in coeliac disease. Aliment Pharmacol Ther 2005;21:515-518.

31. Volta U, Granito A, De Franceschi L, Petrolini N, Bianchi FB. Anti tissue transglutaminase antibodies as predictors of silent coeliac disease in patients with hypertransaminasaemia of unknown origin. Dig Liver Dis 2001;33:420-425.
32. Bardella MT, Vecchi M, Conte D, Del Ninno E, Fraquelli M, Pacchetti S, Minola E, Landoni M, Cesana BM, De Franchis R. Chronic unexplained hypertransaminasemia may be caused by occult celiac disease. Hepatology 1999;29:654-657.

33. Barry RE, Baker P, Read AE. Coeliac disease. The clinical presentation. Clin Gastroenterol 1974;3:55-69.

34. Mylotte M, Egan-Mitchell B, McCarthy CF, McNicholl B. Coeliac disease in the West of Ireland. Br Med J 1973;3:498-499.

35. Seah PP, Fry L, Hoffbrand AV, Holborow EJ. Tissue antibodies in dermatitis herpetiformis and adult coeliac disease. Lancet 1971;1:834-836.

36. Fraser NG, Ferguson A, Murray D. Dermatitis herpetiformis in two patients with idiopathic steatorrhoea (adult coeliac disease). Br Med J 1968;4:30-31.

37. Collin P, Maki M. Associated disorders in coeliac disease: clinical aspects. Scand J Gastroenterol 1994;29:769-775.

38. Reunala T, Collin P. Diseases associated with dermatitis herpetiformis. Br J Dermatol 1997;136:315-318.

39. Ventura A, Neri E, Ughi C, Leopaldi A, Citta A, Not T. Gluten-dependent diabetes-related and thyroid-related autoantibodies in patients with celiac disease. J Pediatr 2000;137:263-265.

40. Holmes GK. Coeliac disease and Type 1 diabetes mellitus - the case for screening. Diabet Med 2001;18:169-177.

41. Collin P, Salmi J, Hallstrom O, Reunala T, Pasternack A. Autoimmune thyroid disorders and coeliac disease. Eur J Endocrinol 1994;130:137-140.

42. Ch'ng CL, Biswas M, Benton A, Jones MK, Kingham JG. Prospective screening for coeliac disease in patients with Graves' hyperthyroidism using anti-gliadin and tissue transglutaminase antibodies. Clin Endocrinol (Oxf) 2005;62:303-306.

43. Zelissen PM, Bast EJ, Croughs RJ. Associated autoimmunity in Addison's disease. J Autoimmun 1995;8:121-130.

44. Myhre AG, Aarsetoy H, Undlien DE, Hovdenak N, Aksnes L, Husebye ES. High frequency of coeliac disease among patients with autoimmune adrenocortical failure. Scand J Gastroenterol 2003;38:511-515.

45. Bottaro G, Cataldo F, Rotolo N, Spina M, Corazza GR. The clinical pattern of subclinical/silent celiac disease: an analysis on 1026 consecutive cases. Am J Gastroenterol 1999;94:691-696.

46. Zauli D, Grassi A, Granito A, Foderaro S, De Franceschi L, Ballardini G, Bianchi FB, Volta U. Prevalence of silent coeliac disease in atopics. Dig Liver Dis 2000;32:775-779.

47. Greco L, De Seta L, D’Adamo G, Baldassarre C, Mayer M, Siani P, Lojodice D. Atopy and coeliac disease: bias or true relation? Acta Paediatr Scand 1990;79:670-674.

48. Farmakis E, Puntis JW, Toumba KJ. Enamel defects in children with coeliac disease. Eur J Paediatr Dent 2005;6:129-132.

49. Smith DM, Miller J. Gastro-enteritis, coeliac disease and enamel hypoplasia. Br Dent J 1979;147:91-95.

50. Mariani P, Mazzilli MC, Margutti G, Lionetti P, Triglione P, Petronzelli F, Ferrante E, Bonamico M. Coeliac disease, enamel defects and HLA typing. Acta Paediatr 1994;83:1272-1275.

51. Cuvellier JC, Vallee L, Nuyts JP. Celiac disease, cerebral calcifications and epilepsy syndrome. Arch Pediatr 1996;3:1013-1019.

52. Volta U, De Giorgio R, Petrolini N, Stangbellini V, Barbara G, Granito A, De Ponti F, Corinaldesi R, Bianchi FB. Clinical findings and anti-neuronal antibodies in coeliac disease with neurological disorders. Scand J Gastroenterol 2002; 37:1276-1281.

53. Luostarinen L, Himanen SL, Luostarinen M, Collin P, Pirttila T. Neuromuscular and sensory disturbances in patients with well treated coeliac disease. J Neurol Neurosurg Psychiatry 2003;74:490-494. 
54. Luostarinen LK, Collin PO, Peraaho MJ, Maki MJ, Pirttila TA. Coeliac disease in patients with cerebellar ataxia of unknown origin. Ann Med 2001;33:445-449.

55. Hadjivassiliou M, Grunewald R, Sharrack B, Sanders D, Lobo A, Williamson C, Woodroofe N, Wood N, Davies-Jones A. Gluten ataxia in perspective: epidemiology, genetic susceptibility and clinical characteristics. Brain 2003;126:685-691.

56. Pereira AC, Edwards MJ, Buttery PC, Hawkes CH, Quinn NP, Giovannoni G, Hadjivassiliou M, Bhatia KP. Choreic syndrome and coeliac disease: a hitherto unrecognised association. Mov Disord 2004;19:478-482.

57. Meloni GF, Dessole S, Vargiu N, Tomasi PA, Musumeci S. The prevalence of coeliac disease in infertility. Hum Reprod 1999; 14:2759-2761.

58. Collin P, Vilska S, Heinonen PK, Hallstrom O, Pikkarainen P. Infertility and coeliac disease. Gut 1996;39:382-384.

59. Acerini CL, Ahmed ML, Ross KM, Sullivan PB, Bird G, Dunger DB. Coeliac disease in children and adolescents with IDDM: clinical characteristics and response to gluten-free diet. Diabet Med 1998;15:38-44.

60. Ashabani A, Abushofa U, Abusrewill S, Abdelazez M, Tuckova $\mathrm{L}$, Tlaskalova-Hogenova $\mathrm{H}$. The prevalence of coeliac disease in Libyan children with type 1 diabetes mellitus. Diabetes Metab Res Rev 2003;19:69-75.

61. Buysschaert M, Tomasi JP, Hermans MP. Prospective screening for biopsy proven coeliac disease, autoimmunity and malabsorption markers in Belgian subjects with Type 1 diabetes. Diabet Med 2005;22:889-892

62. Contreas G, Valletta E, Ulmi D, Cantoni S, Pinelli L. Screening of coeliac disease in north Italian children with type 1 diabetes: limited usefulness of HLA-DQ typing. Acta Paediatr 2004;93:628-632.

63. Mahmud FH, Murray JA, Kudva YC, Zinsmeister AR, Dierkhising RA, Lahr BD, Dyck PJ, Kyle RA, El-Youssef M, Burgart LJ, Van Dyke CT, Brogan DL, Melton LJ 3rd. Celiac disease in type 1 diabetes mellitus in a North American community: prevalence, serologic screening, and clinical features. Mayo Clin Proc 2005;80:1429-1434.

64. Sorensen HT, Thulstrup AM, Blomqvist P, Norgaard B, Fonager $\mathrm{K}$, Ekbom A. Risk of primary biliary liver cirrhosis in patients with coeliac disease: Danish and Swedish cohort data. Gut 1999;44:736-738.

65. Fasano A. European and North American populations should be screened for coeliac disease. Gut 2003;52:168-169.

66. Mulder CJ, Hadithi MM, Rostami K, Goerres MS. Coeliac disease - has the time come for routine mass screening? In 2002-2010-2020? Rom J Gastroenterol 2002;11:179-182.

67. Midhagen G, Jarnerot G, Kraaz W. Adult coeliac disease within a defined geographic area in Sweden. A study of prevalence and associated diseases. Scand J Gastroenterol 1988;23:1000-1004.

68. Volta U, De Franceschi L, Molinaro N, Tetta C, Bianchi FB. Organ-specific autoantibodies in coeliac disease: do they represent an epiphenomenon or the expression of associated autoimmune disorders? Ital J Gastroenterol Hepatol 1997;29:18-21.

69. Collin P, Reunala T, Pukkala E, Laippala P, Keyrilainen O, Pasternack A. Coeliac disease-associated disorders and survival. Gut 1994;35:1215-1218.

70. Counsell CE, Taha A, Ruddell WS. Coeliac disease and autoimmune thyroid disease. Gut 1994;35:844-846.

71. Velluzzi F, Caradonna A, Boy MF, Pinna MA, Cabula R, Lai MA, Piras E, Corda G, Mossa P, Atzeni F, Loviselli A, Usai P, Mariotti S. Thyroid and celiac disease: clinical, serological, and echographic study. Am J Gastroenterol 1998;93:976-979.
72. Kowalska E, Wasowska-Krolikowska K, Toporowska-Kowalska E. Estimation of antithyroid antibodies occurrence in children with coeliac disease. Med Sci Monit 2000;6:719-721.

73. Sategna-Guidetti C, Volta U, Ciacci C, Usai P, Carlino A, De Franceschi L, Camera A, Pelli A, Brossa C. Prevalence of thyroid disorders in untreated adult celiac disease patients and effect of gluten withdrawal: an Italian multicenter study. Am J Gastroenterol 2001;96:751-757.

74. Hakanen M, Luotola K, Salmi J, Laippala P, Kaukinen K, Collin P. Clinical and subclinical autoimmune thyroid disease in adult celiac disease. Dig Dis Sci 2001;46:2631-2635.

75. Carta MG, Hardoy MC, Boi MF, Mariotti S, Carpiniello B, Usai P. Association between panic disorder, major depressive disorder and celiac disease: a possible role of thyroid autoimmunity. J Psychosom Res 2002;53:789-793.

76. Sategna-Guidetti C, Bruno M, Mazza E, Carlino A, Predebon $\mathrm{S}$, Tagliabue M, Brossa C. Autoimmune thyroid diseases and coeliac disease [see comment]. Eur J Gastroenterol Hepatol 1998;10:927-931.

77. Valentino R, Savastano S, Tommaselli AP, Dorato M, Scarpitta MT, Gigante M, Micillo M, Paparo F, Petrone E, Lombardi G, Troncone R. Prevalence of coeliac disease in patients with thyroid autoimmunity. Horm Res 1999;51:124-127.

78. Cuoco L, Certo M, Jorizzo RA, De Vitis I, Tursi A, Papa A, De Marinis L, Fedeli P, Fedeli G, Gasbarrini G. Prevalence and early diagnosis of coeliac disease in autoimmune thyroid disorders [see comment]. Ital J Gastroenterol Hepatol 1999;31:283-287.

79. Berti I, Trevisiol C, Tommasini A, Citta A, Neri E, Geatti O, Giammarini A, Ventura A, Not T. Usefulness of screening program for celiac disease in autoimmune thyroiditis. Dig Dis Sci 2000;45:403-406.

80. Volta U, Ravaglia G, Granito A, Forti P, Maioli F, Petrolini N, Zoli M, Bianchi FB. Coeliac disease in patients with autoimmune thyroiditis. Digestion 2001;64:61-65.

81. Larizza D, Calcaterra V, De Giacomo C, De Silvestri A, Asti M, Badulli C, Autelli M, Coslovich E, Martinetti M. Celiac disease in children with autoimmune thyroid disease. J Pediatr 2001;139:738-740.

82. Meloni GF, Tomasi PA, Bertoncelli A, Fanciulli G, Delitala G, Meloni T. Prevalence of silent celiac disease in patients with autoimmune thyroiditis from Northern Sardinia. J Endocrinol Invest 2001;24:298-302.

83. Mainardi E, Montanelli A, Dotti M, Nano R, Moscato G. Thyroid-related autoantibodies and celiac disease: a role for a gluten-free diet? J Clin Gastroenterol 2002;35:245-248.

84. Lorini R, Larizza D, Scotta MS, Severi F. HLA in Graves' disease coexistent with coeliac disease. Eur J Pediatr 1986; $145: 241$

85. Dalton TA, Bennett JC. Autoimmune disease and the major histocompatibility complex: therapeutic implications. Am J Med 1992;92:183-188.

86. Kaukinen K, Collin P, Mykkanen AH, Partanen J, Maki M, Salmi J. Celiac disease and autoimmune endocrinologic disorders. Dig Dis Sci 1999;44:1428-1433.

87. Badenhoop K, Dieterich W, Segni M, Hofmann S, Hufner M, Usadel KH, Hahn EG, Schuppan D. HLA DQ2 and/or DQ8 is associated with celiac disease-specific autoantibodies to tissue transglutaminase in families with thyroid autoimmunity. Am J Gastroenterol 2001;96:1648-1649.

88. Green JR, Chiew MK, Low HC, Woodrow JC. The association between HLA antigens and the presence of certain diseases. Stat Med 1983;2:79-85.

89. Weetman AP, McGregor AM. Autoimmune thyroid disease: further developments in our understanding. Endocr Rev 1994;15:788-830. 
90. Yanagawa T, Mangklabruks A, Chang YB, Okamoto Y, Fisfalen ME, Curran PG, DeGroot LJ. Human histocompatibility leukocyte antigen-DQA $1 * 0501$ allele associated with genetic susceptibility to Graves' disease in a Caucasian population. J Clin Endocrinol Metab 1993;76:1569-1574.

91. Hunt KA, McGovern DP, Kumar PJ, Ghosh S, Travis SP, Walters JR, Jewell DP, Playford RJ, van Heel DA. A common CTLA4 haplotype associated with coeliac disease. Eur J Hum Genet 2005;13:440-444.

92. Chistiakov DA, Turakulov RI. CTLA-4 and its role in autoimmune thyroid disease. J Mol Endocrinol 2003;31:21-36.

93. King AL, Moodie SJ, Fraser JS, Curtis D, Reid E, Dearlove AM, Ciclitira PJ. Coeliac disease: investigation of proposed causal variants in the CTLA4 gene region. Eur J Immunogenet 2003;30:427-432.

94. Valentino R, Savastano S, Maglio M, Paparo F, Ferrara F, Dorato M, Lombardi G, Troncone R. Markers of potential coeliac disease in patients with Hashimoto's thyroiditis. Eur J Endocrinol 2002;146:479-483.

95. Collin P, Kaukinen K, Valimaki M, Salmi J. Endocrinological disorders and celiac disease. Endocr Rev 2002;23:464-483.

96. Catassi C, Bearzi I, Holmes GK. Association of celiac disease and intestinal lymphomas and other cancers. Gastroenterology 2005;128:S79-S86.

97. Jiskra J, Limanova Z, Vanickova Z, Kocna P. IgA and IgG antigliadin, IgA anti-tissue transglutaminase and antiendomysial antibodies in patients with autoimmune thyroid diseases and their relationship to thyroidal replacement therapy. Physiol Res 2003;52:79-88.

98. d'Esteve-Bonetti L, Bennet AP, Malet D, Hoff M, Louvet JP, Caron P. Gluten-induced enteropathy (coeliac disease) revealed by resistance to treatment with levothyroxine and alfacalcidol in a sixty-eight-year-old patient: a case report. Thyroid 2002;12:633-636.

99. Sategna Guidetti C, Solerio E, Scaglione N, Aimo G, Mengozzi G. Duration of gluten exposure in adult coeliac disease does not correlate with the risk for autoimmune disorders. Gut 2001;49:502-505.

100. Viljamaa M, Kaukinen K, Huhtala H, Kyronpalo S, Rasmussen M, Collin P. Coeliac disease, autoimmune diseases and gluten exposure. Scand J Gastroenterol 2005;40:437-443.

101. Rami B, Sumnik Z, Schober E, Waldhor T, Battelino T, Bratanic N, Kurti K, Lebl J, Limbert C, Madacsy L, Odink RJ, Paskova M, Soltesz G. Screening detected celiac disease in children with type 1 diabetes mellitus: effect on the clinical course (a case control study). J Pediatr Gastroenterol Nutr 2005;41:317-321.

102. Sanchez-Albisua I, Wolf J, Neu A, Geiger H, Wascher I, Stern M. Coeliac disease in children with Type 1 diabetes mellitus: the effect of the gluten-free diet. Diabet Med 2005;22:10791082.

103. Kaspers S, Kordonouri O, Schober E, Grabert M, Hauffa BP, Holl RW; German Working Group for Pediatric Diabetology. Anthropometry, metabolic control, and thyroid autoimmunity in type 1 diabetes with celiac disease: A multicenter survey. J Pediatr 2004;145:790-795.

104. Boudraa G, Hachelaf W, Benbouabdellah M, Belkadi M, Benmansour FZ, Touhami M. Prevalence of coeliac disease in diabetic children and their first- degree relatives in west Algeria: screening with serological markers. Acta Paediatr Suppl 1996;412:58-60.

105. Koletzko S, Burgin-Wolff A, Koletzko B, Knapp M, Burger W, Gruneklee D, Herz G, Ruch W, Thon A, Wendel U, Zuppinger K. Prevalence of coeliac disease in diabetic children and adolescents. A multicentre study. Eur J Pediatr 1988;148:113-117.

\section{Author Affiliations}

Chin Lye Ch'ng, MRCPI

Department of Gastroenterology

Singleton Hospital, Swansea

United Kingdom

\author{
M. Keston Jones, MD, FRCP \\ Department of Endocrinology \\ Singleton Hospital, Swansea \\ United Kingdom
}

Jeremy G. C. Kingham, MD, FRCP

Department of Gastroenterology

Singleton Hospital, Swansea

United Kingdom 